\title{
MODEL TERAPI IBADAH DALAM MENGATASI KEGERSANGAN SPIRITUAL
}

\author{
Naan \\ UIN Sunan Gunung Djati Bandung \\ E-mail: naan@uinsgd.ac.id
}

\begin{abstract}
ABSTRAK
Ibadah merupakan sekumpulan kegiatan syar'i. Orang yang rajin ibadah adalah orang yang telah menjalankan kewajibannya dalam beragama. Dalam Islam, terdapat banyak ritual ibadah. ibadah yang paling sering dilaksanakan adalah salat. penelitian ini berfokus pada penelitian ibadah. Ibadah menjadi model terapi. Ibadah yang menjadi lokus penelitian adalah salat, puasa dan zikir. Hasil penelaahan data ketiga macam ibadah tersebut menyebutkan bahwa ketiganya dapat memberi dampak signifikan bagi orang yang mengamalkannya. Salat misalnya, tidak hanya sebatas ruku dan sujud, salat dapat memberi efek sehat pada tubuh dan rasa pada batin. Puasa tidak sekedar menahan lapar dan haus. Puasa bisa menjadikan pelakunya berpikir visioner, melampaui batas akal, meyakini kehidupan berikutnya. Zikir dapat mengingat Allah tanpa henti. Pengingatan ini sebagai tanda mengenal Allah. Orang yang mengenal Allah adalah orang yang mengenal dirinya sendiri.
\end{abstract}

KATA KUNCI :

Ibada; Salat; Puasa; Zikir; Spiritual

DOI: https://doi.org/10.15575/saq.v2i2.2971

\section{A. PENDAHULUAN}

Masyarakat merupakan sekumpulan manusia yang menetap bersama pada suatu tempat yang sama - satu dengan yang lainnya saling berinteraksi - berdasarkan pada tradisi tertentu yang terus-menerus dan terikat pada identitas yang terbangun kolektif. ${ }^{1}$ Interaksi antar sesama manusia yang berkelanjutan itu akan menjadi kebiasaan, hingga akhirnya dapat melahirkan sebuah tradisi. Misalnya kebiasaan masyarakat pedesaan yang selalu bersama dan bergotong-royong dalam membuat rumah, atau kebiasaan selalu bersama dalam memanen padi di sawah.

Tidak berbeda dengan di desa, masyarakat perkotaan juga memiliki kebiasaan yang sudah menjadi tradisi. Meskipun tidak semua orang kota suka olahraga bersama di tempat-tempat umum, kegiatan itu merupakan fakta sosial yang tidak bisa dikesampingkan. Olahraga bersama tersebut didasarkan kepada kebutuhan individu akan kesehatan sebagai penyeimbang dari rutinitas kerja seminggu yang padat. Di sinilah peran kebersamaan muncul, menyentuh sisi individualistik seseorang sebagai makhluk sosial.

Fakta sosial tersebut di atas telah menunjukkan, betapa kuatnya pengaruh kegiatan-kegiatan bersama terhadap seseorang, dimana gagasan-gagasan umum bisa diterima. Emile Durkheim, sebagaimana dikutip oleh Dadang Kahmad, telah memberikan definisi yang jelas dengan mengatakan bahwa fakta sosial ditandai dengan adanya cara berbuat

\footnotetext{
${ }^{1}$ Kuntjacaraningrat, , Pengantar Ilmu antropologi, ,
} Jakarta, 1990 (Jakarta: Rineka Cipta, 1990), 146-147. 
yang tetap atau tidak; bisa juga dikatakan bahwa fakta sosial adalah suatu metode berbuat yang umum dalam kerumunan masyarakat yang terlahir secara alamiah, hingga terlepas dari manfestasi personal. ${ }^{2}$

Orang beragama, terlebih umat Islam, mendapatkan pengajaran tentang keseimbangan, keadilan dan visi rasa. Haidar Bagir berpendapat bahwa perjalanan hidup seorang manusia di muka bumi ini bermula dari Allah, hidup di alam penciptaan, dan akan kembali kepada Allah. Ini sesuai dengan firman Allah yang bermakna bahwa kita adalah makhluk yang ada dalam genggaman Allah yang suatu saat akan kembali kepada-Nya. ${ }^{3}$

Dalam ajaran tasawuf istilah kembali adalah tobat. Bertobat berarti tidak melakukan lagi perbuatan yang ditentang oleh syariat, sebaliknya melakukan tindakan-tendakan yang terpuji. Menurut al-Ghazali, jalan sufi ini merupakan permulaan latihan jiwa, pembersih sifat-sifat buruk sekaligus melepaskannya, dan berkonsentrasi hanya kepada yang Maha Pencipta. ${ }^{4}$

Semua orang memiliki harapan untuk kembali kepada kebaikan - dalam perspektif diri, agama dan keyakinannya akan Allah kapan pun dan di mana pun. Untuk meniti jalan tobat dibutuhkan keyakinan yang lurus, pasrah dan bersifat totalitas kepada Allah. Bagi sebagian orang, hal tersebut mungkin menyulitkan, terlebih bagi individu yang absen dalam ritual keagamaan.

Kembali kepada Allah membutuhkan cara yang tepat. Cara yang tepat untuk bertobat adalah dengan banyak beribadah kepada Allah. Dalam beribadah itulah, pertobatan menjadi khusuk dan terasa sempurna.

Dari asumsi di atas, role model terapi ibadah dirasa perlu dan sangat dibutuhkan. Role model terapi ibadah dimaksud di sini dalam persepektif sufisme, namun membutuhkan pengujian dari perspektif yang lain, perspektif agama-agama.

\footnotetext{
${ }^{2}$ Dadang Kahmad, Sosiologi Agama, Rosdakarya (Bandung: Remaja Rosda Karya, 2000), 4.

${ }^{3}$ Alquran Surat Albaqarah ayat 156
}

Mengkaji agama atau aliran sebuah agama dengan pendekatan Psikologi atau pun sosiologi tidak akan mengungkap secara mendalam tentang teologi atau ajaran suatu agama, karena teologi bukanlah wilayah penelitian ilmu psikologi atau pun sosiologi. Untuk itu yang menjadi fokus penelitiannya adalah mengenai perilaku keagamaan orang yang diteliti, karena perilaku keagamaan merupakan efek dari keberagamaan pemeluknya. Hal ini bersesuaian dengan teori fungsionalisme, dimana para ahli sosiologi menaruh minat pada penelitian agama bukan pada keyakinan tentang Tuhan suatu agama, tetapi efek dari agama itu sendiri. Hal ini didasarkan pada argumentasi: pertama, banyak sistem agama yang bercampur bersama, karena fungsi integratif yang sama yang dijalankan. Kedua, banyak sistem keyakinan yang sangat berbeda, tanpa acuan kepada Tuhan atau dewa atau roh halus atau kehidupan sesudah mati, eksis setara dengan agama. di sini ada fungsi yang dijalankan sama, adanya kesetaraan.

Bagi individu yang tergabung dalam sebuah komunitas, atau pun sekte atau aliran sebuah agama, efek agama merupakan hasil dari sebuah riyadhah. Rasa spiritual yang diperoleh melalui pengalaman ini, akan termanifestasikan melalui nilai-nilai etik dalam kehidupan sehari-hari.

Salah satu yang bisa disebut sebagai aliran agama dalam Islam adalah tarekat. Sebagai sebuah komunitas, tarekat eksis karena para anggotanya. Di dalam komunitas tarekat ini, terjadi proses transformasi sosial terkendali yang terbuka dan berkeadaban

Tranformasi sosial yang terjadi pada para pengikut tarekat ini menarik untuk dicermati dan diteliti. Bukan aspek keyakinannya yang menjadi objek kajian, melainkan hasil dari keberagamaannya dalam bertarekat. Hal ini bisa mengacu kepada karakteristik analisis fungsionalis, antara lain: Pertama, yang diperhatikan adalah akibat dari sebuah keyakinan - perbuatan dari aktivitas atau

\footnotetext{
${ }^{4}$ Abu al-Wafa al-Ghanimi al-Taftazani, Sufi dari zaman ke zaman (Bandung: Pustaka, 1997), 234.
} 
keyakinan tersebut dibandingkan dari aspekaspek keyakinan itu sendiri; Kedua, titik tekan utama dapat keluar dari eksplanasi warga masyarakat yang diteliti tentang kegiatan mereka demi terungkap pentingnya fungsional sesungguhnya dari keyakinan dan tingkahlaku yang dilembagakan. ${ }^{5}$

Berdasarkan teori yang digunakan dalam penelitian ini, dua pertanyaan penelitian yang diajukan memungkinkan diperoleh jawabannya melalui upaya pemecahan masalah sesuai dengan data dan fakta yang ditemukan baik melalui book survey.

Berdasarkan kerangka berfikir di atas, hipotesis yang diajukan tergambarkan dalam fokus penelitian yang dirinci dalam bentuk pertanyaan penelitian. Hipotesis ini memungkinkan untuk diteliti dan dapat diperoleh pemecahan masalahnya. Diharapkan, hasil pemecahan masalah ini dapat memberikan kontribusi bagi dunia akademik maupun kebijakan praktis terkait dengan Tasawuf Psikoterapi dan pengamalan agama.

Dua pertanyaan penelitian yang telah penulis ajukan membuka kemungkinan diperolehnya beberapa alternatif pemecahan masalah, yaitu bahwa dasar-dasar teologis yang menunjukkan manusia harus selalu menggunakan "ibadah" dalam menjalani kehidupan yang dipahami dan dideskripsikan oleh para Sufi. Dasar-dasar teologis ini bersumber dari teks suci (Alquran) dan perilaku yang dicontohkan oleh Rasulullah (AsSunnah). Berdasarkan pemahaman dan praktek Ibadah yang dilakukan para Sufi itu dapat dijadikan dasar bagi proses penyembuhan manusia dari kegersangan spiritual.

\section{B. PEMBAHASAN}

Penelitian ini adalah penelitian dengan pendekatan kualitatif yang didukung oleh data kepustakaan. Dari sifat penelitian ini dimungkinkan dapat mendeskripsikan dasardasar teologis cara penyembuhan melalui ibadah dan menemukan tahapan, bentuk, dan pola atau model ibadah dalam mengisi

\footnotetext{
${ }^{5}$ Pip Jones, Pengantar Teori-Teori Sosial, Yayasan Obor Indonesia, Jakarta, 2009, 59
}

kegersangan spiritual pada masyarakat perkotaan.

Atas dasar itu, metode yang digunakan dalam penelitian adalah metode deskriptif dengan melibatkan kajian sosio-psikologis sebagai alat untuk menganalisis fenomena dan data yang diperoleh. Pendekatan sosiologis dan fenomenologis digunakan sebagai bidang yang dikaji dalam mempelajari fenomena yang terjadi dan ditemukan di lapangan. Ranah kajian penelitian mencakup dasar teoritis dan empiris mengenai tobat sebagai proses terapis, yang direpresentasikan melalui para Sufi. Terapi ibadah, merupakan hasil kajian teoritis dan pengalaman keagamaan. Oleh karena itu, pendekatan dan analisis psikologi-terapan banyak digunakan dalam penelitian ini.

\section{Psikoterapi sebagai Metode Pengobatan}

Psikoterapi lahir sebagai respons dari penderitaan manusia. Pederitaan yang menghantui kehidupan manusia memotivasi nya untuk mencari cara untuk mengurangi, arau sebisa mungkin melenyapkan penderitaan tersebut. Mungkin selama penderitaan itu masih ada psikoterapi akan tetap ada dengan berbagai bentuk dan metodologinya.

Pada sejarahnya, psikoterapi mengalami beberapa tahap perkembangan, di mana setiap tahapan memiliki karakteristik yang berbeda.Tahapan pertama dari psikoterapi adalah magis. Pada tahapan ini orang-orang yang mengalami gangguan jiwa diasumsikan mendapatkan gangguan dari luar dirinya, semacam gangguan dari roh halus. Pada tahapan magis ini dukun-dukun atau shaman menjadi 'ahli-ahli kejiwaan' yang akan memberikan penanganan pada penderita gangguan tersebut. Karena orang yang mengalami gangguan jiwa pada tahapan ini dianggap mendapat gangguan roh halus, jin, atau setan, maka penanganannya terkadang bersifat tidak manusiawi. Tidak jarang para penderita gangguan jiwa mendapatkan perlakuan kasar seperti pemukulan, atau pemasungan. ${ }^{6}$

\footnotetext{
${ }^{6}$ Corsini, Raymond, ed. Psikoterapi Dewasa ini. Yogyakarta: ikon, 2003.
} 
Tahapan kedua dalam psikoterapi adalah tahapan agama. Pada tahapan ini menitikberatkan kekuatan supranatural yang akan menghilangkan penderitaan manusia. Di dalam agama manusia dijanjikan akan terlepas dari penderitaan jika menjalankan ajaran-ajaran agamanya. Pada tahapan ini para tokoh agamalah yang mengambil peran penting dalam menangani para penderita gangguan jiwa. Meskipun belum ada metode yang terstruktur seperti sekarang, pada tahap ini para penderita gangguan jiwa tidak mendapatkan perlakuan kasar seperti sebelumnya.Etika yang diajarkan agama membuat mereka diperlakukan secara lebih manusiawi. ${ }^{7}$

Tahap yang ketiga yaitu tahapan filosofis.Banyak yang menghargai ajaranajaran etika agama, namun mengingkari adanya kekuatan supranatural yang mengatur segalanya di alam semesta.Mereka beralih kepada penalaran filosofis untuk mengatasi berbagai macam permasalahan hidup.Termasuk masalah penderitaan. ${ }^{8}$

Tahap keempat dari perkembangan psikoterapi adalah tahapan medis (pengobatan).Perkembangan ilmu pengetahuan telah membawa manusia pada perubahan paradigm, tak terlepas dalam psikoterapi.Gangguan kejiwaan dalam tahapan ini dianggap sebagai gangguan yang bersifat fisika kimiawi dalam otak manusia.Sehingga jika penderita gangguan jiwa mendapatkan diagnosa yang benar, maka dapat ditentukan prosedur pengobatan macam apakah yang sesuai.Pengobatan medis mengandalan obatobatan, injeksi, dan prosedur pembedahan untuk menangani pasien gangguan jiwa. Dan kelak akan menjadi bagian dari ilmu kedokteran yang dinamakan psikiatri. ${ }^{9}$

Tahap kelima dari evolusi psikoterapi adalah tahapan psikologi. Psikologi merupakan suatu ilmu yang mempelajari fenomena tingkah laku manusia.Teori-teori psikologi seperti psikoanalisa yang digagas oleh Sigmund Freud, dan psikologi analitik yang diciptakan oleh Carl Gustav Jung menjadi acuan dalam merumuskan suatu treatmen psikoterapi untuk menangani penderita gangguan jiwa. ${ }^{10}$

Psikoanalisa memiliki pendekatan problem solving atau pemecahan masalah. Psikoanalisa mencoba untuk mencari tahu penyebab-penyebab ketidaknyamanan emosional yang dialami pasien dan mencoba berbagai macam solusi berdasarkan analisis yang telah dilakukannya.Hubungan antara pasien dan terapis dalam psikoanalisa adalah saling melengkapi. Pasien memproduksi materi berupa fantasi-fantasi dan sejarah hidup masa lalunya. Pasien menceritakan semua itu kepada terapis dan terapis mendengarkannya untuk diinterpretasikan. Seorang terapis seharusnya adalah orang yang berpribadi hangat, bersikap menerima dan tidak menghakimi.

Menurut Reuben Fine dalam ulasannya tentang psikoanalisa, seorang pasien biasanya membutuhkan waktu satu jam hingga lima jam dalam seminggu selama proses penyembuhannya. Sesi psikoterapi berlangsung dengan keadaan pasien berbaring diatas dipan, dan pasien diminta untuk berasosiasi bebas yaitu dengan mengatakan apa saja yang muncul dibenaknya. Suatu sesi berlangsung antara 45 menit hingga satu jam.Aktivitas pasien diatas dipan pada esensinya berupa pembicaraan dan pengungkapan perasaan-perasaan, sensasisensasi, memori-memori berikut asosiasinya. Pada umumnya, sang analis duduk dibelakang pasien, memberi komentar-komentar beragam serta memberikan interpretasi-interpretasi disaat yang tepat.

Aktivitas menganalisa yang serius bisa berlangsung lama mulai dari satu tahun hingga sepuluh tahun bahkan lebih. Tahapan-tahapan pokok proses yang harus dilalui oleh para analisan (pasien) adalah sebagai berikut: pemantapan hubungan; analisa yang berlangsung sangat akrab; mengalami dan menghayati krisis penyembuhan pertama; pendalaman terapi; penerobosan dan
${ }^{7}$ Corsini, Psikoterapi Dewasa ini,.

${ }^{8}$ Corsini, Psikoterapi Dewasa ini,.
${ }^{9}$ Corsini, Psikoterapi Dewasa ini,.

${ }^{10}$ Corsini, Psikoterapi Dewasa ini, 
pendobrakan (yang biasanya memakan waktu lama), dan proses akhir penyembuhan. ${ }^{11}$

\section{Psikoterapi Batin}

Terapi berarti mengobati. Sebuah usaha untuk memperoleh kesembuhan. Dalam terminologi sufi, mengobati bisa disebut dengan menyucikan diri. Menyucikan diri berarti membersihkan diri lahir dan diri batin.

Syeikh Abdul Qodir al-Jilani menyatakan bahwa penyucian lahir diatur oleh agama dengan cara membasuh tubuh dengan air yang suci. Sementara menyucikan batin dengan cara sadar bahwa ada noda dalam diri karena berdosa. Penyucian dimensi esoterik ini butuh bimbingan dari seorang guru batin. Membasuu tubuh dengan air maksudnya membasahi sebagian dari anggota tubuh dalam wudhu. Ketika wudhu bisa batal karena keluar sesuatu dari dua lubang atau batal karena syar'i, maka seseorang harus memperbarui wudhunya agar tetap dalam menjaga kesuciannya. Dalam sabdanya, Nabi Muhammad Saw., memberi pesan yang kuat tentang wudhu, beliau menyatakan bahwa wudhu dapat memperbarui kepercayaan seorang hamba, keimanannya bercahaya dan lebih bercahaya. Memperbarui kesucian dengan wudhu berarti mengkilapkan cahaya di atas cahaya. Wudhu dapat menjadi jalan sucinya batin. Namun kesucian batin ini akan lenyap oleh sifat-sifat tercela. Kemarahan, kebencian, kesombongan, dan melakukan penipuan adalah bentuk-bentuk perbuatan yang merusak bersihnya hati. ${ }^{12}$

Dimensi esoteris lainnya adalah jiwa. Jiwa butuh disucikan. Sachiko Murata $^{13}$ menyebutkan bahwa tugas manusia adalah mengajak jiwa ke arah kebahagiaan menjauhkannya dari ketercelaan - dan berdamai dengan Tuhan. Kebahagiaan manusi mencapai puncaknya ketika jiwa disucikan. Sebalikanya titik kulminasi penderitaan terletak pada perbuatan jiwa yang bebas selaras dengan sifat alamiahnya. Bukankah, Allah telah menyampaikan bahwa orang yang beruntung adalah orang yang menyucikan jiwanya, sebaliknya, orang yang merugi adalah orang yang membuat dirinya kotor dengan perbuatan dosanya.

\section{Praktek Ibadah sebagai Terapi}

Untuk membersihkan hati, para syaikh dalam berbagai thariqah atau tarekat (Jalan sufi menuju Allah) sangat menganjurkan agar memperhatikan praktik yang ditetapkan oleh Allah. Mereka berpandangan bahwa sesuai dengan hikmah tak terbatas Zat Yang Maha Bijaksana, semakin manusia tenggelam dalam berbagai urusan duniawi dan sibuk dengan halhal materil maka ia semakin beroleh banyak kesulitan dan bertambah kesal. ${ }^{14}$ Oleh karena itu diperlukan berbagai amalan-amalan yang dapat mendekatkan diri kita kepada Allah, dan memalingkan kita dari keduniaan sehingga kita tidak terlalu disibukkan oleh mengurusinya.

\section{1) Salat}

Mir Valiuddin menyatakan, secara harfiah, salat bisa berarti doa atau sembahyang. Salat juga merupakan cara memohon ampun, meminta belas kasih dan pengharapan kasih sayang. Namun demikian, bila terjebak pada arti ini saja, hal itu akan membatasi arti salat secara substansi. Praktek salat dapat mencitrakan individu sebagai orang yang religius. Nabi menegaskan bahwa perbedaan orang yang beriman dengan yang lain adalah salat. ${ }^{15}$

Salat yang dilaksanakan sehari semalam berjumlah lima waktu, yaitu diwaktu Fajar, zuhur, asar, magrib, dan isya. Waktu salat ini ditetapkan berdasarkan perputaran matahari dan planet lainnya. Waktu-waktu pelaksanaan ditetapkan menurut perjalanan matahari dan planet-planet di langit. Dengan mengikuti waktu-waktu salat ini, manusia benar-benar
${ }^{11}$ Corsini, Psikoterapi Dewasa ini, 48.

12 Syeikh Abdul Qadir Al-Jailani, Sirr Al-Asrar (Ebook: http://hikmah.sitesled.com, 2006), tulisan ke-16.

13 Sachiko Murata, The Tao of Islam (Bandung: Mizan, 2000), 366-368.
14 Mir Valiuddin. Zikir \& Kontemplasi dalam Tasawuf. Bandung: Pustaka Hidayah, 2000. 62.

15 Syaikh Hakim Muinuddin Chisyti. Penyembuhan Cara Sufi. Jakarta: Lentera, 1999, 148. 
sudah terbiasa dengan gerakan-gerakan planet, pergantian musim dan perbedaan geografis. individu berpadu dengan siklus alamiah dari alam semesta. ${ }^{16}$

Orang yang salat adalah orang yang ingin menemukan jalan menuju Tuhan. Salat sebagai penyucian diri, sebagai pertobatan, sebuah upaya dalam mengendalikan hawa nafsu. Dalam salat, ayat Aquran dibacakan, ada rukuk sebagai tanda kerendahan hari, ada sujud yang menggantikan pengenalan diri. Ada syahadat pengganti keakraban, dan diakhiri dengan salam sebagai simbol dari terlepas dari dunia dan keterikatan. ${ }^{17}$

Salat dilaksanakan untuk meraih keteguhan hati. ${ }^{18}$ Karena alasan ini, banyak syeikh sufi yang memerintahkan muridnya untuk melakukan salat, di luar salat wajib, dengan jumlah rakaat sangat banyak hingga mencapai ratusan dengan tujuan supaya badan murid mereka terbiasa dengan ibadah. Orang orang yang mencapai keistikamahan pun melakukan banyak salat sebagai tanda syukur atas nikmat Allah yang telah dilimpahkan.

Dalam pandangan lain, alasan orang harus melaksanakan salat antara lain, pertama, memiliki harapan yang kuat untuk menundukkan hawa nafsu; Kedua, untuk meniadakan kekuatan-kekuatan alamiah yang buruk; Ketiga, demi merahi sucinya hati nurani; dan Keempat, kesempurnaan mujahadah. ${ }^{19}$

Dengan salat juga berbagai ketegangan psikis bisa dikurangi. Salat yang khusyuk memberikan kedamaian, dan kestabilan terhadap manusia. Sehingga ia bisa melawan kegelisahan yang timbul dari kesedihan dan ketergesa-gesaan. Salat juga mendorong untuk berpikir positif dalam hidup.Dengan selalu bersyukur dan berdo'a kepada Allah, salat mengarahkan pikiran manusia hanya untuk memikirkan berbagai kenikmatan yang dia miliki, bukan berbagai kekurangannya. Lalu,

\footnotetext{
${ }^{16}$ Syaikh Hakim Muinuddin Chisyti, Penyembuhan Cara Sufi, 149-150.

17 Al-Hujwiri. Kasyful Mahjub. Bandung: Mizan, 1992., 269-270.

${ }^{18}$ Al-Hujwiri, Kasyful Mahjub,270.

${ }^{19}$ Al-Hujwiri, Kasyful Mahjub,271.
}

perasaannya pun akan berubah mengikuti pikirannya. ${ }^{20}$

Allah telah mengaitkan antara mengabaikan salat dan mengikuti hawa nafsu. Melaksanakan salat membuat seorang muslim mampu menguasai berbagai keinginan hawa nafsunya, karena dia membuat akalnya terjaga hingga tidak tunduk kepada berbagai keinginan hawa nafsu yang bertentangan dengan tujuan asasinya, yaitu ridha Allah swt. Salat membuat akal berada di posisi pemimpin hingga dia tidak tunduk kepada hawa nafsu. ${ }^{21}$

\section{2) Puasa}

Menurut Syeikh Abdul Qadir AlJailani, ${ }^{22}$ Puasa terdiri dari puasa yang disyariatkan dan puasa batin. Puasa yang disyariatkan berarti menahan makan dan minum,menahan diri dari berhubungan intim suami istri mulai dari terbitnya matahari hingga terbenam. Adapun puasa batin adalah puasa yang lebih kepada perbuatan psikologis dengan menjaga lima indra dan pikiran dari tindakan tercela.

Alhujwiri berpendapat bahwa hakikat puasa adalah keberpantangan. Metode tasawuf atau tarekat adalah berpantang. Pantangan terendah dalam puasa yaitu lapar. Lapar secara universal terpuji dalam pandangan hukum dan akal. Keberpantangan berarti menahan dan menyertakan banyak kewajiban, seperti: menahan diri dari makanan dan minuman, dan menundukkan mata dari nafsu birahi, dan menjaga telinga dari perkataan-perkataan buruk tentang orang lain, dan menahan lidah dari kata-kata kotor dan percuma serta menjaga badan dari tuntutan keduniawian dan keingkaran kepada-Nya. ${ }^{23}$

Dalam sabdanya, Nabi Muhammad Saw., menyatakan puasa itu untuk Allah, oleh

\footnotetext{
${ }^{20}$ Muhammad Bahnasi, Shalat Sebagai Terapi Psikologi, 75.

${ }^{21}$ Muhammad Bahnasi, Shalat Sebagai Terapi Psikologi, 96.

${ }^{22}$ Syeikh Abdul Qadir Al-Jailani, Sirr Al-Asrar.

${ }^{23}$ Al-Hujwiri, Kasyful Mahjub, 287.
} 
karena itulah hanya Allah yang akan membalasnya. Tersirat dikatakan, puasa tidak bisa diukur oleh orang yang melaksanakannya, apakah puasanya diterima atau tidak diterima. Puasa bersifat rahasia, bahkan sangat rahasia. Puasa hanya milik Tuhan dan hambanya yang berpuasa.

Dalam sabdanya yang lain, Nabi Muhammad menyatakan kebahagiaannya orang yang berpuasa. Berbahagia saat berbuka dan berbahagia saat melihat Tuhan. Kebahagiaan pertama bersifat lahiriah seperti Makan, minum dan hubungan intim suami istri. Kebahagiaan lainnya adalah berhari raya idul fitri. Setelah tiga puluh hari berpuasa, akhirnya diakhiri dengan datangnya bulan syawal. Kebahagiaan pertama ini sangat terukur baik secara matematika maupun logika manusia. Pemahaman ini masuk pada kategori puasa lahir

Kebahagiaan kedua adalah melihat Allah. Ini visioner. Melihat Allah bisa dalam pengertian melihat dengan bashirah, mata batin. Melihat berarti keyakinan bahwa amal ibadah puasa sampai kepada Allah. Lebih dari itu, melihat bisa diartikan bahwa seorang hamba akan bertemu secara langsung di hari akhirat. Kegembiraan yang kedua ini tidak bisa diukur oleh akal belaka, tapi hanya bisa disentuh oleh keimanan seseorang kepada Allah. Puasa jenis ini adalah puasa batin. Puasa batin menyentuh ranah hakikat yang dapat meningkatkan keakraban hamba dengan Tuhannya.

Dilihat dari fungsinya, puasa merupakan serangkaian teknik terapi dalam menjaga dan mengobati tubuh dari hal-hal yang merusaknya. Dengan puasa, kesehatan tubuh dapat terjaga dengan baik dan ganjaran kecerdasan spiritual yang sangat luar biasa. ${ }^{24}$

Puasa merupakan pedoman dalam mengontrol dan menghilangkan hasrat-hasrat

\footnotetext{
${ }^{24}$ Syaikh Hakim Muinuddin Chisyti, Penyembuhan Cara Sufi, 146.

${ }^{25}$ Syaikh Hakim Muinuddin Chisyti, Penyembuhan Cara Sufi, 138.

${ }^{26}$ Syaikh Hakim Muinuddin Chisyti, Penyembuhan Cara Sufi, 141.
}

tubuh. Tanpa kendali yang kokoh, cinta duniawi dan sejenisnya menjadi sebab bagi sebagian besar penyakit. ${ }^{25}$ Puasa dapat memunculkan kesabaran dan pengorbanan. Puasa adalah sebuah rahasia. ${ }^{26}$ Nilai spiritualitas terletak pada kerahasiaan ini. Manusia tidak tahu apakah puasanya berkualitas dihadapan Allah. Kerahasiaan inilah yang menjadi sebab, puasa itu milik Allah dan Dialah yang akan membalasnya.

Puasa adalah bentuk pengobatan alamiah yang paling dikenal. Sebagai sebuah metode, puasa menghentikan makanan dan minuman masuk ke dalam tubuh selama jangka waktu cukup lama. ${ }^{27}$

Meskipun tujuan utama dan efek-efek yang diharapkan dari puasa itu terjadi di alam ruhani dan evolusinya, namun tetap menjadi kenyataan bahwa kebanyakan orang memperoleh juga hasil secara jasmaniah dari puasa. ${ }^{28}$ Penyakit, menurut Syekh Muinuddin Chisti, seringkali dihubungkan dengan pencernaan nutrient yang tidak sempurna pada satu atau beberapa tahap pencernaan. Selama puasa, pekerjaan biasa yang berlangsung dalam pencernaan dikurangi, sehingga memungkinkan tubuh untuk mengeluarkan bahan-bahan yang tak berguna serta memperbaiki kerusakan akibat kesalahan pola makan yang berlangsung lama. ${ }^{29}$

Puasa digambarkan oleh Syekh Muinuddin Chisti sebagai metode detoksifikasi alami. Selama menjalankan puasa racun-racun yang menumpuk ditubuh dikeluarkan melalui mekanisme tubuh itu sendiri. Proses yang terjadi saat pembersihan biasanya berupa: mimisan, muntah-muntah, diare (mencret), keringat, dan urinasi (kencing). Proses-proses tersebut biasanya diidentifikasi sebagai penyakit oleh kedokteran modern, namun sebenarnya proses tersebut merupakan tahapan yang harus dijalani untuk pembersihan kembali

\footnotetext{
${ }^{27}$ Syaikh Hakim Muinuddin Chisyti, Penyembuhan Cara Sufi, 137.

${ }^{28}$ Syaikh Hakim Muinuddin Chisyti, Penyembuhan Cara Sufi, 143.

${ }^{29}$ Syaikh Hakim Muinuddin Chisyti, Penyembuhan Cara Sufi, 144.
} 
tubuh dari racun-racun yang menumpuk didalamnya.

Bagi orang yang tidak ingin mengalami proses detoksifikasi alami tersebut, atau yang menganggapnya sebagai penyakit biasanya beralih menggunakan obet-obatan kimia untuk menghilangkan gejala yang ditimbulkan sebagai efek detoksifikasi tersebut. Namun penggunaan obat tersebut, walaupun dapat secara singkat membuat seseorang terlihat normal, dapat merusak mekanisme pembersihan alami tubuhnya. Mungkin yang terjadi adalah sebaliknya, racun kimia menumpuk dalam tubuhnya.

Fungsi puasa adalah untuk menekan segala hasrat sesaat dan mengalihkan manusia kepada malaikat yang tidak memiliki keinginan-keinginan jasmani dan tetap tenggelam menyembah Allah. Orang yang melakukan segala bentuk pelanggaran dalam berpuasa seperti berbohong, menggunjing, adalah bagaikan orang yang mencuci wajahnya dengan sabun kemudian membersihkannya dengan handuk yang dipenuhi dengan air kencing.

Lapar karena puasa dapat mempertajam kecerdasan dan meningkatkan pikiran dan kesehatan. Orang yang lapar adalah orang yang sedang membuat tubuhnya menderita. Namun tidak bagi ruhaninya, dengan lapar, kondisi batin orang yang berpuasa mengalami peningkatan kepekaan. Hati tercahayakan dan jiwa tersucikan. Ruh orang yang berpuasa pun dekat dengan Tuhan. Orang yang lapar karena berpuasa dapat melepaskan ikatan-ikatan lahiriah yang membelenggunya. Ia menempatkan dirinya pada derajat tertinggi dihadapan Allah. ${ }^{30}$

Maulana Syah Waris Hasan ${ }^{31}$ berpendapat bahwa pengaruh puasa yang penting adalah menghilangkan kotoran yang dikumpulkan jiwa dalam bersahabat dengan badan. Manfaat lainnya mengingatkan kita pada kebiasaan-kebiasaan kita yang lama dan yang baru.

\section{3) Zikir}

Zikir merupakan bentuk ibadah yang sangat mudah dilakukan.Tidak seperti ibadahibadah lain yang telah ditetapkan waktu dan ketentuan-ketentuan lainnya. Menurut Ibnu Abbas, zikir bisa dilakukan kapan saja dan di mana saja. Secara harfiah, arti zikir atau al$d z i k r$ adalah ingat. Zikir berarti mengingat Allah. Dengan mengingat Allah kita akan merasakan penjagaan dan pengawasan-Nya. Orang yang beriman adalah orang-orang yang selalu ingat kepada Allah dan selalu mengingatnya. ${ }^{32}$

Allah swt berfirman dalam hadis qudsi, "Aku seperti yang disangkakan hamba-Ku, dan Aku bersama mereka jika mereka mengingatku. Jika hamba-Ku mengingat-Ku di dalam dirinya, Aku akan mengingat mereka di dalam diri-Ku, dan jika hamba-Ku menyebut-Ku dalam sebuah majelis, Aku akan menyebut mereka dalam majelis yang lebih baik dari majelisnya. Jika dia mendekati-Ku, Aku akan mendekatinya sehasta; Jika dia mendekati-Ku sehasta, Aku akan mendekatinya sedepa; jika dia datang kepada-Ku dengan berjalan, Aku akan datang kepadanya dengan berlari."

Menurut syaikh Hakim Muinuddin Chisti, pengingatan dalam satu hal hanya dapat diartikan sebagai semacam proses pemikiran formal terhadap Allah atau atribut-atribut-Nya. Nabi Muhammad Saw. bersabda , bahwa " $\mathrm{La}$ ilaha illallah adalah bentuk pengingatan yang paling utama kepada Allah Yang Mahakuasa." 33 Objek segenap ibadah adalah mengingat Allah, dan hanya terus-menerus mengingat Allah sajalah yang bisa melahirkan cinta kepada Allah serta mengosongkan hati dari kecintaan dan keterikatan pada dunia fana ini. $^{34}$

\footnotetext{
${ }^{33}$ Syaikh Hakim Muinuddin Chisyti, Penyembuhan Cara Sufi, 214.

${ }^{34}$ Syaikh Hakim Muinuddin Chisyti, Penyembuhan Cara Sufi.
}

${ }^{30}$ Al-Hujwiri, Kasyful Mahjub, 290.

31 Maulana Syah Waris Hasan, Bimbingan Murid Spiritual (Bandung: Marja, 2002), 42.

${ }^{32}$ Arman Yurisaldi Saleh, Berzikir untuk Kesehatan Saraf (Jakarta: Zaman, 2010), 30. 
Mir Valiuddin mengatakan bahwa, "Ajaran Islam yang paling dasar dan paling penting tersirat dalam syahadah atau "pengakuan keimanan", La illaha illa Allah, yang berarti "tiada tuhan selain Allah" atau "tidak ada objek yang layak dan pantas disembah kecuali Allah". Dan ini tak lain dan tak bukan ialah terus-menerus mengingat Allah." Dia pun melanjutkan bahwa "sebagai hasil dari zikir, hati pun kosong dari cinta pada segala sesuatu serta terpupus dari semuanya. Kemudian, ia pun cenderung pada Allah semata." Oleh karena itu zikir dapat memenuhi hati seseorang hanya dengan perasaan cinta kepada Allah semata. Dan kehilangan cinta kepada selain-Nya. Dan seseorang dapat terhindarkan dari perasaan duka dan kesedihan yang bersifat duniawi. ${ }^{35}$

Tidak berzikir sama artinya dengan melupakan Allah. Dan melupakan Allah berarti telah melupakan diri sendiri. Bila orang sudah lupa dengan dirinya berarti tidak mengenal dirinya dengan baik. orang yang tidak mengenal dirinya dengan baik akan mengalami ketidakseimbangan dalam hidupnya. Gersang secara spiritual.

Orang yang melupakan diri sendiri sesungguhnya telah tersesat. Alquran mengatakan yang artinya, "Dan barangsiapa berpaling dari pengajaran Allah Yang Maha Pengasih (Alquran), Kami Biarkan setan (menyesatkannya) dan menjadi teman karibnya." (QS. Az-Zukhruf [43] : 36)

Ini berarti bahwa berpaling dari mengingat Allah menyebabkan diri dikuasai oleh setan (atau kekuatan-kekuatan bukan Tuhan) yang setiap saat mendorong seseorang serta membisikkan berbagai kejahatan ke dalam hati. Setan baru meninggalkan seseorang kalau dia sudah berhasil mempurukklan dan menjerumuskannya ke dalam neraka (atau menyimpang dari jalan Allah dan kebaikan). Manakala berbagai kekuatan jahat, yang memalingkan hati manusia dari jalan Ilahi, telah menghujam kuat dalam hati seseorang, maka jiwanya pun tersesat sedemikian rupa sehingga ia bahkan tidak tahu bahwa Allah itu ada. Tidak menginat Allah menyebabkan hatinya dikuasai kekuatan-kekuatan jahat. ${ }^{36}$

Tujuan dari mengingat Allah secara terusmenerus untuk membangkitkan kecintaan kepada Allah. Menurut kaum sufi, sebab penciptaan dan sumber kebijaksanaan adalah cinta ini.

Ada banyak zikir yang bisa diamalkan, namun menurut para Sufi lebih mengutamakan berzikir dengan mengucapkan secara berulangulang nama Zat Ilahi, yakni Allah, dan zikir nafy wa itsbat, yakni dzikr penafian dan penegasan, yaitu zikir La Ilaha illa Allah. Para Sufi memilih zikir nafy wa itsbat ini karena Nabi saw sendiri pun mengutamakannya.

Menurut Mir Valiuddin zikir La Illaha illa Allah inilah inti dan saripati semua zikir. Inilah pusat keesaan Allah, tauhid, dan juga cahaya yang sangat terang benderang. Alquran menjelaskan secara terinci makna dan pengertiannya. Zikir ini menafikan semua tuhan palsu dan menegaskan Hakikat Tunggal. Zikir tidak hanya menafikan tuhan-tuhan palsu, melainkan juga semua objek yang bersifat sementara serta menjalin hubungan erat Allah.

Syekh Abdul Khaliq al-Syabrawi menjelaskan bahwa, "Sikap teliti harus dilakukan oleh orang-orang yang menggunakan lafaz baik ini sebagai untuk memanjangkan suku kata ' $l a$ ', melafalkan dengan jelas huruf "I" pada ilaha, melafalkan ha dengan ringan, segera berhenti pada huruf " $h$ " di akhir nama Allah (agar tidak membuatnya menjadi $h a$ ), dan tidak boleh ada jarak pemisah antara ha dan ilallah, sebab jika tidak demikian, ia akan menjadi $y a$, dan zikir mereka menjadi layilaha yang bukan lagi kalimat tauhid. Dengan demikian, tak ada pahala dan tak aada pengaruh yang diharapkan darinya. Kebanyakan orang berzikir terjerumus ke dalam kelalaian ini. Ketika memulai mengucapkan la ilaha, orang yang berzikir harus menghilangkan dari hatinya semua objek penyembahan selain Allah dan mengucapkan la ilaha dengan mantap dan bersemangat,
${ }^{35}$ Mir Valiuddin, Zikir \& Kontemplasi dalam Tasawuf, 91 .
${ }^{36} \mathrm{Mir}$ Valiuddin, Zikir \& Kontemplasi dalam Tasawuf, 92. 
seraya berpaling kesebelah kiri dadanya. Dia harus bersikap khusyuk dan terpesona, memejamkan mata, dan tetap suci secara ritual dari segala hal yang kotor."

\section{KESIMPULAN}

Model Terapi Ibadah adalah model terapi yang menggunakan ritual ibadah sebagai metode terapi. Ibadah yang dijadikan sebagai model terapi adalah salat, puasa dan zikir. Terapi dengan pendekatan salat dapat menyehatkan tubuh, karena dalam salat ragam gerakan yang memberi keseimbangan. Salat juga dapat menyucikan jiwa dan hati.

Puasa sebagai terapi. Tubuh didik untuk dapat menahan diri dari asupan makanan dan minuman yang berlebihan. Puasa juga telah membiarkan tubuh rehat sejenak dari asupan berbagai makanan. Puasa terbagi dua, puasa lahir dan puasa batin. Puasa lahir dibatasi oleh menahan lapar dan haus. Sedangkan puasa batin adalah puasa yang bersifat hakikat. Puasa ini dapat mengenalkan hamba dengan Tuhannya.

Terapi zikir. Zikir artinya mengingat. Mengingat Allah dapat menentramkan jiwa. Jiwa yang tenteram akan membawa kepada kedamaian. zikir dapat meningkatkan kecerdasan spiritual. indikator cerdas secara spiritual adalah selalu mengingat Allah kapanpun dan dimanapun berada.

\section{DAFTAR PUSTAKA}

Abu al-Wafa al-Ghanimi al-Taftazani, Sufi dari zaman ke zaman (Bandung: Pustaka, 1997)

Al-Hujwiri. Kasyful Mahjub. (Bandung: Mizan, 1992)

Arman Yurisaldi Saleh, Berzikir untuk Kesehatan Saraf (Jakarta: Zaman, 2010)

Corsini, Raymond, ed. Psikoterapi Dewasa ini. (Yogyakarta: ikon, 2003)

Dadang Kahmad, Sosiologi Agama, Rosdakarya (Bandung: Remaja Rosda Karya, 2000)

Kuntjacaraningrat, , Pengantar Ilmu antropologi, , Jakarta, 1990 (Jakarta: Rineka Cipta, 1990)

Maulana Syah Waris Hasan, Bimbingan Murid Spiritual (Bandung: Marja, 2002)
Mir Valiuddin. Zikir \& Kontemplasi dalam Tasawuf. (Bandung: Pustaka Hidayah, 2000)

Muhammad Bahnasi. Shalat Sebagai Terapi Psikologi. (Bandung: Mizania, 2008).

Pip Jones, Pengantar Teori-Teori Sosial, (Jakarta: Yayasan Obor Indonesia, 2009)

Sachiko Murata, The Tao of Islam (Bandung: Mizan, 2000)

Syaikh Hakim Muinuddin Chisyti. Penyembuhan Cara Sufi. (Jakarta: Lentera, 1999)

Syeikh Abdul Qadir Al-Jailani, Sirr Al-Asrar (Ebook: http://hikmah.sitesled.com, 2006)

Syekh Abdul Khaliq al-Syabrawi. Buku Saku Psikologi Sufi: memandu anda mencerdaskan dan menumbuhkan jiws mulia. (Jakarta: Penerbit Zaman, 2012). 